ESJ Social Sciences

\title{
Exploring the Lived Experiences of Inclusive Education Teachers Handling Students With Intellectual Disability: A Mixed Method Approach
}

\author{
Soren R. Sanchez \\ Liza Chua \\ Rogaciano B. Melgar \\ University of Cebu - Main Campus, Philippines
}

Doi:10.19044/esj.2021.v17n12p90

Submitted: 25 January 2021

Accepted: 31 March 2021

Published: 30 April 2021
Copyright 2021 Author(s)

Under Creative Commons BY-NC-ND

4.0 OPEN ACCESS

Cite As:

Sanchez, RS., Chua, L., and Melgar, BR. (2021). Exploring the Lived Experiences of Inclusive Education Teachers Handling Students With Intellectual Disability: A Mixed Method Approach. European Scientific Journal, ESJ, 17(12), 90. https://doi.org/10.19044/esj.2021.v17n12p90

\begin{abstract}
This paper focuses on exploring the lived experiences of inclusive education teachers handling students with intellectual disability in terms of their stressors, coping mechanisms, fulfilling experiences, and opportunities. A mixed method using questionnaire and one-on-one interview were employed in gathering the needed quantitative and qualitative data from the 13 purposively chosen respondents. Frequency and simple weighted mean were used in interpreting the quantitative data, while the Groenewald's process of phenomenological analysis was employed to extract themes from the qualitative data. Results revealed that the students' behavioral issues were the only potential stressors of the inclusive teachers. They coped via using cognitive, social, and physical coping resources. Students' positive transformations, understanding the child through team teaching, and road to salary augmentation were the themes generated as their fulfilling experiences and opportunities. It is recommended that schools offering inclusive
\end{abstract}


education should equip their teachers with pedagogical knowledge in handling the behavioral issues of students with special needs through providing relevant trainings.

Keywords: Inclusive education, lived experiences, stressors, coping mechanisms, fulfilling experiences and opportunities 


\section{Introduction}

Inclusive education has been the trend in special education all over the world. Most countries across the world are adopting this move in education. Philippine is one of those countries which adopted this curricular innovation. However, the implementation of inclusive education in both public and private schools across the country was never a cinch to the teachers.

There are quite a number of public and private schools in Cebu City and across parts of the Philippines which offer inclusive education. Agbenyaga (2007) elaborated that the lack of skills and professional competence to effectively deliver the lesson to the special-need children may impose frustrations to teachers in inclusive classroom. Hence, having a degree and trainings in special education (SPED) is of great advantage to a teacher in an inclusive classroom.

Unfortunately, there are teachers accommodating learners with special needs without sufficient background in special education in some schools in Cebu City. The researchers had known of few inclusive education teachers who are non-SPED graduates handling students with intellectual disability. These teachers shared their sentiments, burnouts and stressors in handling students with special needs and regular students in one setting.

One of the problems they encountered is the deficiency of professional competence in teaching students with special needs in concurrence with the regular students. They asserted that they were not trained during their undergraduate years with the pedagogical practices in handling special students. Also, providing differentiated instruction, varying visual materials, and assessing special students' learning had caused them frustration. However, some non-SPED teachers reported that they were sent to seminars but asserted that those were inadequate for them to feel confident in teaching and dealing with the special needs of learners. Their lack of skills added up to their burnouts. Moreover, these inclusive education teachers also encountered problems in managing the class. They reported that the lack of background towards special education greatly affects their performance and effectiveness as teachers. With these, they explained that their level of confidence as inclusive education teachers was low. It is for these shared sentiments and burnouts this study was carried out.

The findings of this study served as cognizance among the school administrators of the lived experiences of the inclusive education teachers. This study attempts to capture their experiences in handling students with intellectual disability in terms of their potential stressors, coping mechanisms, and their perceived fulfilling experiences and opportunities. 


\section{Objectives of the Study}

This study aimed to explore the lived experiences of inclusive education teachers handling student with intellectual disability (ID). Specifically, this study sought to determine their: (1) profile in terms of baccalaureate degree/ educational attainment, number of years teaching, number of students with ID in the class, and relevant trainings; (2) stressors in terms of administrative issues, support issues, student behaviour issues, classroom issues, parent issues, personal competence issues, professional competence issues, and personal competence issues; (3) teachers' coping mechanism in terms of cognitive, social, emotional, spiritual/philosophical, physical; and (4) fulfilling experiences and opportunities.

\section{Literature Review}

Teaching is indeed a fulfilling profession. For some, it is considered as a noble calling rather than a profession. Its responsibilities do not limit facilitating learning, but it extends beyond developing the learners holistically. These are reasons which affirm that teachers hold a very stressful accountability. Teaching profession ranked in the top quartile as one of the most complicated professions (Snowman \& Biehler, 2000). Teaching is one of the top five most-stressful career choices and has the highest rate of career shifting to other professions (Lewis et al., 2011). Leitwood and Riehl (2003) also supported the contention that teaching in general is a stressful occupation.

For the past few decades, education among many countries had its major shift from separating students with special needs to include them in the regular classroom. This is called inclusive education or inclusion which in most countries is supported on a legal basis. Brackenreed (2011) negated that teaching SPED students together with the regular ones doubles the stress than teaching regular students solely. Hence, inclusion is a major stressor of the teachers.

When there is an imbalance between one's resources in coping with one's occupational demands in the work field, a stress occurs (Esteve, 2000; Wood \& McCarthy, 2002; Troman \& Woods, 2001). If these demands tend to exceed one's coping resources, they are likely to experience burnouts. A prolonged agony of occupational stress may deteriorate one's quality of teaching (Jaoul et al., 2004).

One of the major challenges any educational institution is facing in the recent years is the implementation of inclusive education (Sharma \& Desai, 2002). The stress and burnouts are caused by parent-teacher relationship, student behavioural problems, co-worker relationship conflict, and the demands of schools and parents (Skaalvik \& Skaalvik, 2007). The lack of support system from the administration and co-workers are few of the 
stressors of inclusion teachers (Sloan \& LaPlante, 2002). Alghazo and Gaad (2004) averred that there is a very minimal support for inclusion. This usually occurs when learners have more challenging conditions and support needs (Talmor et al., 2005).

The lack of professional training and achievement are also contributing factors to the stress of the inclusive education teachers (Salend, 1998; Friedman, 2000; Izci, 2005). Nevertheless, there are some inclusion teachers who had trainings related to special education but raised their apprehension. These educators expressed that their trainings were not adequate to prepare them to teach inclusive classrooms (Danne \& Smith, 2000). The lack of training in special education causes one to hold negative attitude towards inclusion (Leatherman \& Niemeyer, 2005). Teachers having apprehensive attitudes may implement activities that promote exclusion rather than inclusion inside the classroom (Sharma et al., 2008). On the other hand, teachers with positive attitudes towards inclusion have higher tendencies to employ teaching strategies which accommodate individual differences (Forlin, 2010; Campbell et al., 2003).

With those stressors faced by inclusive education teachers, abundant resources of coping mechanisms are needed. Coping mechanism is the ability to handle stress more effectively (Hopkins, 2014). Most of the inclusion teachers solved their day-to-day stressors in the work field by actively finding solution to the problem, receiving social and emotional support from fellow teachers, reorganizing teaching situation, having active parental involvement, and changing pedagogical strategies (Skaalvik \& Skaalvik, 2007). Additionally, maintaining a positive self-image and outlook in life, constantly believing and motivating oneself may help inclusive education teachers cope with their stressors (Nketsia et al., 2016).

\section{Methodology}

Mixed method was utilized in the study as it involves both quantitative and qualitative data. To gather the quantitative data on the respondents' stressors and coping mechanism, the Inclusive Education Teacher Stress and Coping Mechanism Questionnaire by Forlin (2001) was adopted. The tool was modified making it a localized version. It is a likerttyped questionnaire that has three (3) parts. The first part aims to gather personal information from the respondents. The second part gathers data on their stressors and the third gathers their coping mechanisms. One-on-one interview with open-ended questions was carried out to gather qualitative data on their fulfilling experiences and opportunities. The interview guide questions underwent scrutiny and validation check by two (2) experts. 
However, below are the sample guide questions:

1. How is your experience in handling students with intellectual disability in an inclusive setting?

2. How do you describe your life as an inclusive education teacher?

3. How do you describe your usual day? Please elaborate.

4. What is/are your greatest accomplishment/s as an inclusive education teacher handling students with intellectual disabilities?

This study totally involved 13 inclusive education teachers handling students with intellectual disability from private and public schools of Cebu City, Philippines. They were determined using purposive sampling. During the data collection process, they were asked to answer the questionnaire first. After then, a one-on-one interview was performed that lasted for 30-40 minutes with their consent.

The collected quantitative data were presented in a tabular form. Their scores were analyzed and interpreted through getting the weighted mean. The qualitative data were interpreted using thematic approach following Groenewald's process of phenomenological data analysis which observes 5 phases: (1) bracketing and coding of responses; (2) delineating units of meaning; (3) formulation of themes using the clustered units of meaning; (4) summarizing the verbatim answers, validating and modifying it as necessary; and (5) extracting general themes (Groenewald, 2004).

\section{Results and Discussions for Quantitative Data}

Table 1 below presents the profile of the inclusive education teachers handling students with intellectual disability.

Table 1. Respondents' Profile

\begin{tabular}{cccc}
\hline Variable & Category & Frequency & Percentage \\
\hline School & Private & 6 & $46.15 \%$ \\
& Public & 7 & $53.85 \%$ \\
No. of Students & $1-2$ & 10 & $76.92 \%$ \\
with ID in the & $3-5$ & 2 & $15.38 \%$ \\
Classroom & $6-7$ & 1 & $7.69 \%$ \\
& & 7 & $53.85 \%$ \\
Educational & Non-SPED Graduate & 3 & $23.08 \%$ \\
Attainment & Non-SPED Graduate w/ & 0 & $0.00 \%$ \\
& MAED units & 3 & $23.08 \%$ \\
& SPED Graduate & & \\
& SPED Graduate w/ MAED & units &
\end{tabular}




\begin{tabular}{cccc} 
No. Years of & Less than a year & 2 & $15.38 \%$ \\
Teaching & $1-5$ & 4 & $30.77 \%$ \\
& $6-10$ & 2 & $15.38 \%$ \\
& $11-15$ & 1 & $7.69 \%$ \\
& 16 up & 4 & $30.77 \%$ \\
Relevant & 0 & 4 & $30.77 \%$ \\
Training & $1-2$ & 8 & $61.54 \%$ \\
& $3-4$ & 1 & $7.69 \%$ \\
\hline $\mathrm{n}=13$ & & &
\end{tabular}

As depicted in Table 1, seven (7) of the respondents were teaching in private school, while six (6) were teaching in public schools. The most number of students with ID included in an inclusive classroom is seven (7), while the least is one (1). This result supplies evidence that there are more students with ID being integrated in private inclusive classrooms than in public inclusive classroom in Cebu City, Philippines. With this, public inclusive education teachers most probably experience fewer problems than those private inclusive education teachers as they have smaller quantity of students with ID in their classrooms. In comparison, they only need less amount of time for adjustment, individual education plan (IEP), and lesson plan making.

With respect to educational attainments and relevant trainings, results revealed that there are more non-SPED graduates handling inclusion than those SPED graduates. Moreover, the results showed that five (5) of the respondents have taught inclusive classes for more than 10 years and all of them have attended less than 5 relevant trainings. This means that the schools they are teaching have not been procuring them with trainings on teaching inclusive classrooms. The lack of training in dealing with both regular students and special-need students in one setting imposed stresses and burnouts towards inclusion teacher, causing them to hold negativities on inclusion implementation (Leatherman \& Niemeyer, 2005). 
Table 2 below shows the administrative issues as contributing stressors of inclusive education teachers.

Table 2. Administrative Issues Stressors

\begin{tabular}{|c|c|c|}
\hline Descriptions & Weighted Mean & Remarks \\
\hline Funding & 1.54 & \\
\hline Obtaining & 2.15 & Does Not Apply \\
\hline information & 2.15 & Not \\
\hline Record keeping & 2.38 & Stressful \\
\hline $\begin{array}{l}\text { Accountability of educational } \\
\text { outcomes }\end{array}$ & $\begin{array}{l}2.31 \\
2.31\end{array}$ & \\
\hline Support Personnel Coordination & 2.00 & \\
\hline
\end{tabular}

Routines

Physical Adaptation

IEP Planning

Adjusting units plans

Taking the responsibility of the child's welfare
Somewhat

Stressful

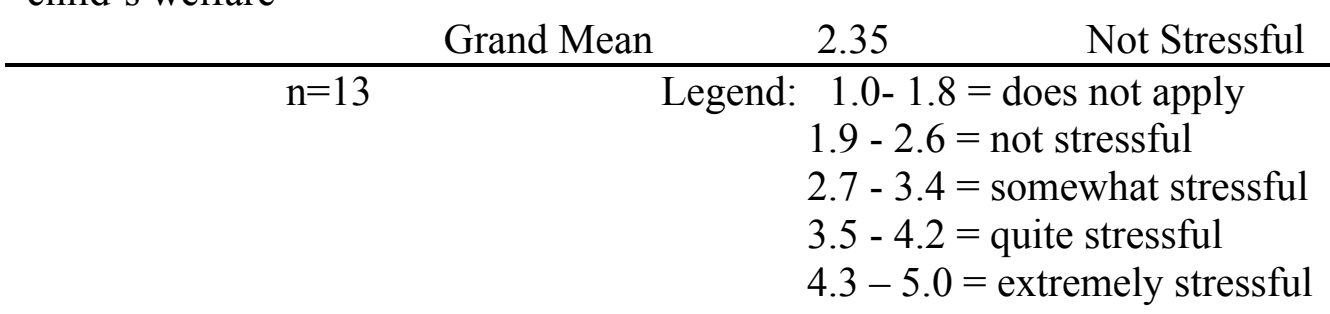

Out of ten (10) administrative stressors, only three (3) were perceived as somewhat stressful by the inclusive education teachers. In total, the administrative issues have a grand mean of 2.35 which is not stressful. Clear enough, the inclusive education teachers' accountability on the student's learning and paper-work responsibilities did not impose significant stress and burnout on them. This finding contradicts the claim of Skaalvik and Skaalvik (2007) that papers-works related responsibilities and the pressure of child's learning compels stress on the inclusion teachers. It is possible that on the first few months of teaching, these paper-work related responsibilities could be the sources of stress. However, after few months of adjusting and getting use to the teaching routines, these responsibilities were not anymore perceived as stressors. 
Table 3 below depicts the support issues as potential stressors of inclusive education teachers.

Table 3. Support Issues Stressors

\begin{tabular}{lcc}
\hline \multicolumn{1}{c}{ Descriptions } & Weighted Mean & Remarks \\
\hline Accessing speech therapy & 1.69 & Does Not Apply \\
Speech and language & 1.62 & \\
& & \\
Occupational therapy & 1.92 & \\
Physical therapy & 1.85 & Not \\
Resource teacher & 2.08 & Stressful \\
Allocating teacher aid & 1.85 & \\
Employing teacher aid & 1.85 & Somewhat \\
Replacement during sick leave & 2.00 & Stressful \\
Childs' educational resources & & Not Stressful \\
Class Resources & 2.77 & \\
\multicolumn{1}{c}{ Grand Mean } & 3.00 & \\
& 2.06 & Legend: $1.0-1.8=$ does not apply \\
& $1.9-2.6=$ not stressful \\
& $2.7-3.4=$ somewhat stressful \\
& $3.5-4.2=$ quite stressful \\
& $4.3-5.0=$ extremely stressful
\end{tabular}

Among the ten (10) support issues, only two (2) were perceived as somewhat stressful. It obtained a weighted mean of 2.06 which means not stressful. In general, the support issues do not entail stress towards the inclusive education teachers. They less likely encountered difficulty in finding support for educational resources and accessing paraprofessionals in special education. Intellectual disability, depending on its case, requires less to no support from the paraprofessionals such as the physical therapist, occupational therapist, and speech therapist in general. These students usually require task analysis of academic instruction and self-help skills trainings (Inciong et al., 2007). With this, support issues do not act as stressors for the inclusive education teachers. 
Table 4 below presents the students' behavior issues as contributing stressors of inclusive education teachers.

Table 4. Student Behavior Issues Stressors

\begin{tabular}{|c|c|c|}
\hline Descriptions & Weighted Mean & Remarks \\
\hline Limited speech & 2.54 & \\
\hline Manipulative & 2.62 & \\
\hline Over loving & 2.31 & Not \\
\hline Unaware of danger & 2.54 & Stressful \\
\hline Poor mobility & 2.15 & \\
\hline Verbally rude & 2.62 & \\
\hline Unpredictable reactions & 2.38 & \\
\hline Runs away & 2.62 & \\
\hline Behaviour problems & 2.38 & \\
\hline Short attention span & 3.00 & \\
\hline Poor communication skills & 2.69 & \\
\hline Attention seeking & 2.77 & Somewhat \\
\hline Hyperactive & 3.15 & Stressful \\
\hline Withdrawn & 2.92 & \\
\hline Dominates classmates & 2.69 & \\
\hline Disturbs others & 2.91 & \\
\hline Throws tantrums & 3.40 & \\
\hline Physically attacks & 2.85 & \\
\hline Inappropriate social skills & 3.73 & Quite Stressful \\
\hline Grand Mean & 2.77 & Somewhat Stressful \\
\hline $\mathrm{n}=13$ & \multicolumn{2}{|c|}{$\begin{aligned} \text { Legend: } & 1.0-1.8=\text { does not apply } \\
& 1.9-2.6=\text { not stressful } \\
& 2.7-3.4=\text { somewhat stressful } \\
& 3.5-4.2=\text { quite stressful } \\
& 4.3-5.0=\text { extremely stressful }\end{aligned}$} \\
\hline
\end{tabular}

Out of the nineteen (19) indicators under the student behaviour issues, results indicated that there were ten (10) issues which were perceived by the teachers as somewhat and quite stressful. In its totality, student behaviour issues got a weighted mean of 2.77 which is somewhat stressful. This confirms that inclusive education teachers encountered dilemma in addressing students' misbehavior in the classroom. Few respondents shared that they were having difficulty with their students with intellectual disability being too sensitive, portraying childish attitude, and sometimes aggressive 
behavior. This confirms the finding of the study of Agbenyega (2007). He found out that the teachers' major concern was on their lack of skills to effectively deal with special-need students in an inclusive setting.

Table 5 below presents the classroom issues as potential stressors of inclusive education teachers.

Table 5. Classroom Issues Stressors

\begin{tabular}{|c|c|c|}
\hline Descriptions & Weighted Mean & Remarks \\
\hline Hygiene issues & 2.46 & \\
\hline $\begin{array}{l}\text { Child's interpersonal relationship } \\
\text { with other students }\end{array}$ & 2.54 & $\begin{array}{c}\text { Not } \\
\text { Stressful }\end{array}$ \\
\hline Sexual behaviour & 2.54 & \\
\hline Time available for other students & 2.62 & \\
\hline Monitoring other students & 2.38 & \\
\hline The class is disrupted by the child & 2.31 & \\
\hline Grand Mean & 2.48 & Not Stressful \\
\hline $\mathrm{n}=13$ & \multicolumn{2}{|c|}{$\begin{array}{ll}\text { Legend: } & 1.0-1.8=\text { does not apply } \\
& 1.9-2.6=\text { not stressful } \\
& 2.7-3.4=\text { somewhat stressful } \\
& 3.5-4.2=\text { quite stressful } \\
& 4.3-5.0=\text { extremely stressful }\end{array}$} \\
\hline
\end{tabular}

As portrayed in Table 5, results show that all of the issues under classroom category got an average of 2.62 and less. This reveals that the inclusive education teachers perceived them as not stressful. This notifies that in its totality, inclusive education respondents experienced insignificant difficulty in monitoring the students' relationship with their peers in the classroom. Those SPED-graduate teachers are most likely to possess positive attitudes in managing the inclusive classrooms; thus, they are more successful (Orel et al., 2004). In contrast, those who are not are expected to have dealt this issue on their first few months of teaching.

Table 6 below portrays the parent issues as potential stressors in teaching inclusive classrooms as perceived by the inclusive education teachers. 


\begin{tabular}{lcc}
\hline \multicolumn{1}{c}{ Descriptions } & Weighted Mean & Remarks \\
\hline Excessive meetings & 1.77 & Does Not \\
Parent/teacher tension & 1.69 & Apply \\
& & \\
Limited contact & 2.15 & Not \\
$\begin{array}{l}\text { Parent(s) in the classroom } \\
\text { Lack of understanding }\end{array}$ & 1.85 & Stressful \\
$\begin{array}{l}\text { Lack of understanding of the } \\
\text { child's prognosis }\end{array}$ & 1.92 & \\
Unwillingness of the parent(s) to & 1.92 & \\
support & & \\
Socio-economic disadvantage & 2.00 & Not Stressful \\
\multicolumn{1}{c}{ Grand Mean } & & \\
& Legend: 13.90 & $1.0-1.8=$ does not apply \\
& $1.9-2.6=$ not stressful \\
& $2.7-3.4=$ somewhat stressful \\
& $3.5-4.2=$ quite stressful \\
& $4.3-5.0=$ extremely stressful
\end{tabular}

All of the indicators under parent issues got a weighted mean of 2.15 and less than that means not stressful and does not apply. The inclusive education teachers did not have dilemma in dealing and collaborating with parents. They did not encounter difficulty in seeking help and reporting the child's strengths, weaknesses, and progress to the parents. Additionally, it can be implied that the inclusive education teachers were comfortable and open towards discussing with the parents any concerns regarding the learning of the students. This finding contradicts the claim of Skaalvik and Skaalvik (2007) that the parent-teacher relationship is an additional stress to the inclusion teachers. 
Table 7 below portrays the professional competence issues as potential stressors in teaching inclusive classrooms.

Table 7. Professional Competence Issues Stressors

\begin{tabular}{ccc}
\hline Descriptions & Weighted Mean & Remarks \\
\hline Insufficient pre-service education & 2.15 & \\
Inadequate in-service education in & 2.07 & Not \\
SPED & 2.46 & Stressful \\
Inadequate in-service education in & & \\
meeting the child's educational needs & 2.23 & \\
$\quad \begin{array}{c}\text { Sustaining an active learning } \\
\text { environment }\end{array}$ & 2.62 & \\
$\begin{array}{c}\text { Determining how much to challenge the } \\
\text { child }\end{array}$ & 2.54 & Not \\
Confusing laziness with the child's & 2.31 & Stressful \\
$\quad$ inability & & \\
Ability to teach other students & & \\
effectively & & \\
$\quad$ Grand Mean & 2.34 & \\
n=13 & $1.0-1.8=$ does not apply \\
& $2.7-3.4=$ somewhat stressful
\end{tabular}

Overall, the professional competence issues gained a weighted mean of 2.34. This indicates that it did not inflict stress towards the inclusive education teachers. Though most of the respondents were non-SPED graduates, their professional competence in teaching inclusive classrooms was not considered as stressful. However, they reported that during the first few months of teaching inclusive classrooms, professional competence was deemed questionable. Nevertheless, during the later months when they have already adjusted the routines, teaching inclusive classes was not perceived as stressful anymore. They shared that seeking solace and assistance from their co-teachers contributed to their speedy adjustment. This contradicts the assertion of Agbenyaga (2007) that the lack of skills and professional competence as well as the insufficient prior exposure and knowledge in special education (Izci, 2005) can adversely affect the effectiveness of the inclusive education teacher. 
Table 8 below displays the personal competence issues as potential stressors in teaching inclusive classrooms.

Table 8. Personal Competence Issues Stressors

\begin{tabular}{|c|c|c|}
\hline Descriptions & Weighted Mean & Remarks \\
\hline Meeting the child's needs & 2.23 & \\
\hline $\begin{array}{l}\text { Undertaking tasks associated with the } \\
\text { child's condition e.g. toileting }\end{array}$ & 1.42 & $\begin{array}{c}\text { Not } \\
\text { Stressful }\end{array}$ \\
\hline Empathising with parents & 2.15 & \\
\hline Responding to the child's personality & 2.54 & \\
\hline Maintaining the child's safety & 2.15 & \\
\hline Maintaining the safety of the other & 2.31 & \\
\hline children & 2.54 & \\
\hline $\begin{array}{l}\text { Meeting the parent(s) expectations } \\
\text { Socio-economic disadvantage }\end{array}$ & 2.23 & \\
\hline Grand Mean & 2.26 & $\begin{array}{c}\text { Not } \\
\text { Stressful }\end{array}$ \\
\hline Leger & \multicolumn{2}{|c|}{$\begin{array}{ll}\text { Legend: } & 1.0-1.8=\text { does not apply } \\
& 1.9-2.6=\text { not stressful } \\
& 2.7-3.4=\text { somewhat stressful } \\
& 3.5-4.2=\text { quite stressful } \\
& 4.3-5.0=\text { extremely stressful }\end{array}$} \\
\hline
\end{tabular}

As exuded on the table, all of indicators under personal competence issues are having weighted mean of 2.54 and less. Likewise, its total weighted mean is 2.26 which denotes that inclusive education teachers did not experience difficulty in teaching students with intellectual disability in as far as their personal abilities, skills, knowledge, and self-efficacy are concerned. With this result, it can be implied that the respondents have high beliefs in their innate abilities to teach student with intellectual disabilities in inclusive classrooms.

Table 9 below illustrates the findings on the cognitive coping resources as one of the coping mechanisms employed by the inclusive education teachers. 


\begin{tabular}{ccc}
\hline Descriptions & Weighted Mean & Remarks \\
\hline Develop other interest outside school & 3.38 & \\
Concentrate on what has to be done next & 3.69 & Somewhat \\
Assure yourself that things will get well & 3.85 & Useful \\
Get the child moved to a special classroom & 2.92 & \\
$\quad$ or school & & \\
Don't think it too much & 2.85 & \\
Enlist support & 2.69 & Quite \\
Look on the bright side of things & 3.92 & Useful \\
Think about how a person you know would & 3.46 & Somewhat \\
handle the situation & 3.77 & Useful \\
Come up with different solutions & 4.00 & \\
Make a plan of action & 3.35 & \\
\multicolumn{2}{c}{ Grand Mean } & \\
$\mathrm{n}=13$ & Legend: $1.0-1.8=$ I do not use \\
& $1.9-2.6=$ not useful \\
& $2.7-3.4=$ somewhat useful \\
& $3.5-4.2=$ quite useful \\
& $4.3-5.0=$ extremely useful
\end{tabular}

The table reveals that all the indicators of cognitive coping mechanisms are useful as perceived by the respondents. Overall, the cognitive coping mechanisms gained a grand mean of 3.35 which means somewhat useful. Therefore, majority of the inclusive education teachers used cognitive coping resources as their way of coping with their stressors. They maintained a positive mindset and outlook towards teaching inclusive classes. They tend to focus more on what their students can do, instead of what the students cannot do. They tend to be optimistic in life in general. A good way to cope up with the currently-faced stress is by maintaining a positive mindset and outlook towards teaching students with exceptionalities (Antoniou et al., 2009). 
Table 11. Philosophical/Spiritual Coping Resources

\begin{tabular}{|c|c|c|}
\hline Descriptions & Weighted Mean & Remarks \\
\hline Use alcohol or medication & 1.62 & I Do Not Use \\
\hline Seek transfer from the school & 1.54 & \\
\hline Resigning from teaching & 1.38 & \\
\hline Meditation & 1.21 & Not Useful \\
\hline Seek spiritual/ religious support & 3.00 & \\
\hline Draw on past experiences & 3.15 & Somewhat \\
\hline Leave the child to work independently & 2.62 & Useful \\
\hline Maintain sense of humour & 3.77 & $\begin{array}{l}\text { Quite } \\
\text { Useful }\end{array}$ \\
\hline Grand Mean & 2.42 & Not Useful \\
\hline $\mathrm{n}=13$ & \multicolumn{2}{|c|}{$\begin{array}{l}1.0-1.8=\text { I do not use } \\
1.9-2.6=\text { not useful } \\
2.7-3.4=\text { somewhat useful } \\
3.5-4.2=\text { quite useful } \\
4.3-5.0=\text { extremely useful }\end{array}$} \\
\hline
\end{tabular}

The most used philosophical/spiritual coping resource is maintaining a sense of humour with an average of 3.77 that has an interpretation of quite useful. This was confirmed by Brackenreed (2011) in his study on "Identifying Teachers' Strategies for Coping with Perceived Stressors in Inclusive Classrooms." The results unveiled that maintaining a sense of humour and optimism consoles them as they face stressors.

Nonetheless, the least-used coping resource is resigning from teaching which has a mean of 1.38 (I do not use). This vividly implies that these inclusive education teachers oftentimes experienced hardship that imposed high-level stress; hence quitting teaching is never a choice for them. In its totality, philosophical/spiritual coping resources accumulated a weighted mean of 2.42 which is not useful. The inclusive education teachers perceived philosophical/spiritual coping resources as not effective in combating against their encountered stressors. In comparison with the cognitive and social coping mechanisms, philosophical/spiritual coping resources is less likely used.

Table 12 below illustrates the physical coping resources as coping mechanisms used by the inclusive education teachers in dealing with their stressors. 
Table 12. Physical Coping Resources

\begin{tabular}{|c|c|c|}
\hline Descriptions & Weighted Mean & Remarks \\
\hline Physical exercise & 2.92 & $\begin{array}{c}\text { Somewhat } \\
\text { Useful }\end{array}$ \\
\hline Grand Mean & 2.92 & $\begin{array}{c}\text { Somewhat } \\
\text { Useful }\end{array}$ \\
\hline $\mathrm{n}=13$ & $\begin{aligned} \text { Legend: } & 1.0-1.8= \\
& 1.9-2.6= \\
& 2.7-3.4= \\
& 3.5-4.2= \\
& 4.3-5.0=\end{aligned}$ & $\begin{array}{l}\text { not use } \\
\text { seful } \\
\text { what useful } \\
\text { useful } \\
\text { mely useful }\end{array}$ \\
\hline
\end{tabular}

Result unveiled that taking some form of physical exercises such as aerobics or sports is a useful coping mechanism in coping with all the stresses embedded as teacher of students with intellectual disability in an inclusive setting. As exuded on the table, it gained a mean of 2.92 which can be interpreted as somewhat useful. This finding signifies that doing some actions on promoting one's physical wellbeing is a powerful tool in relaxing the mind and body. This therefore makes it an effective resource as a coping mechanism. Physical exercises do not only target the physical wellbeing of an individual, but rather it also improves the mental health of a person. It is believed that a healthy physical wellbeing decreases the level of negative response to stress and allows the teachers handling inclusive classes to recover faster.

Table 13 below illustrates the emotional coping resources as coping mechanisms used by the inclusive education teachers in dealing with their stressors.

Table 13. Emotional Coping Resources

\begin{tabular}{|c|c|c|}
\hline Descriptions & Weighted Mean & Remarks \\
\hline Share feelings with the children in class & 2.15 & I Do Not \\
\hline Keep your feelings to yourself & 1.92 & Use \\
\hline Apply for sick or stress leave & 1.62 & \\
\hline Meditation & 2.42 & Not Useful \\
\hline Write down your feelings & 3.23 & Somewhat \\
\hline $\begin{array}{l}\text { Hope that the situation will go away or be } \\
\text { over }\end{array}$ & 3.23 & Useful \\
\hline Grand Mean & 2.43 & Not Useful \\
\hline
\end{tabular}


$1.9-2.6=$ not useful

$2.7-3.4=$ somewhat useful

$3.5-4.2=$ quite useful

$4.3-5.0=$ extremely useful

As illustrated in the table, the emotional coping resources accumulated a weighted mean of 2.43. This indicates that the inclusive education teachers perceived these coping resources as not useful in general. Most of the respondents did not find reducing stress through writing/journaling and keeping it by themselves as effective as the cognitive and social coping resources. They oftentimes shared their sentiments and burnouts with their colleague rather than keeping it to themselves. They usually shared their sentiments to gain emotional support and comfort. Between male and female teachers, it is the female teachers who are prone to using this kind of coping mechanism (Antoniou et al., 2009).

\section{Results and Discussions for Qualitative Data Fulfilling Experiences and Opportunities}

Adhering to Groenewald's process of phenomenlogical data analysis, there were two (2) extracted general themes of the inclusive education teachers' fulfilling experiences. These are the child's positive transformations and understanding the child's nature through team teaching. Likewise, one (1) general theme extracted as their perceived opportunities is road to salary augmentation.

\section{Theme 1: Child's positive transformations}

Teaching in an inclusive classroom has never been an easy task as it demands a lot of preparations. This task subsumes from preparing varied activities, teaching materials, and assessment tools that can cater both for the regular and SPED students. Managing students' behaviour is also a crucial responsibility of the teacher. However, amidst all the dedication and sacrifices an inclusive education teacher does just to gain extra guarantee of students' learning, a simple student improvement is celebrated. Being able to change students' inappropriate behavior, seeing academic improvement, and social skills improvement are considered as fulfillment. This is manifested by the following respondents.

"To be able to change their bad and inappropriate behaviour. That's already a big thing to me as a teacher with this kind of students." Inclusive Education Teacher Respondent (IETR 2)

"My most fulfilling experience is when the child learns from me. When they have score to present to their parents. When they easily get the lesson even without the help of the shadow teachers" (IETR 2) 
"My greatest accomplish was when I let the child read. I actually had teary eyes back then... hahaha" (IETR 8)

\section{Theme 2: Understanding the child through team teaching}

A regular teacher faces regular students, a self-contained SPED teacher faces all SPED students, but an inclusive education teacher faces both regular and SPED students. This mere fact attests that inclusion is stressful by nature. Nonetheless, embarking on this kind of experience could also be fulfilling. Few respondents shared that one of their fulfilling experiences is to be able to finally understand the nature of their students with intellectual disability. This includes knowing the history of the child and understanding why they behave the way they do. Taking these inputs into consideration led the inclusion teachers to properly deal and teach their students. Consulting and asking suggestions from their colleagues had also helped the teachers to properly handle students with intellectual disability. This is evident by the following respondents:

"In so far, my fulfilling experience was when I finally learned how to handle students with special needs." (IETR 10)

"During my undergraduate years, I was only exposed to regular children, I've learned a lot on how to deal with these children" (IETR 3)

"At first, it was hard for me but as time passed by, it was not that hard anymore because my co-teachers were helping me." (IETR 4)

\section{Theme 3: Road to salary augmentation}

The perceived opportunity of inclusive education teachers having been able to handle students with special needs is that it could be a way to improve one's living. Experience in teaching inclusive education could be one of the many means in ameliorating one's source of income. This is a common presumption among most Filipino teachers, basing it on the notion that special education teachers are always in demand abroad especially in America. It is believed that SPED teachers have more chances of teaching abroad than other specializations of teaching. This is manifested by the following respondents:

"I'm going to tell the truth... hahaha. I'm going to Amerika and be a SPED teacher there." (IETP 3)

"You can go abroad. You will be qualified in applying abroad." (IETP 4)

"I think the opportunities that await me is that we all know that SPED teachers are really in demand in the Philippines and outside Philippines. If you want bigger salary, you can go to the US." (IETP 11) 


\section{Conclusion and Recommendation}

The inclusive education teachers, especially the non-SPED graduates, experienced difficulties in teaching inclusive classrooms during their first few months of teaching. After the adjustment period, out of the seven potential stressors, only the student behavior issues were perceived as stressors by the inclusive education teachers. They armored themselves with cognitive, social, and physical coping resources coupled with their perceived fulfilling experiences and opportunities to combat their stressors. It is therefore recommended that schools offering inclusive education should equip their teachers with pedagogical knowledge on how to handle students with special needs with their misbehavior through providing relevant trainings. It is important to note that the researchers experienced difficulty in looking for inclusive education teachers handling students with intellectual disability. Hence, due to the rarity of the respondents to be involved in the study, the insufficiency of the sample size was its limitation. The future researchers are therefore encouraged to replicate the study with sufficient sample size and to explore also the lived experiences of those teachers handling students with other types of exceptionalities such as autism, emotional and behavioral disabilities, multiple and severe disabilities, deafblindness, learning disabilities and other types of disabilities.

\section{References:}

Agbenyega, J. (2007). Examining Teachers' Concerns and Attitudes to InclusiveEducation in Ghana. International Journal of whole schooling, 3(1), 41-56. Retrieved from https://files.eric.ed.gov/fulltext/EJ847471.pdf.

Antoniou, A. S., Polychroni, F., \& Kotroni, C. (2009). Working with Students with Special Educational Needs in Greece: Teachers' Stressors and Coping Strategies. International Journal of Special Education, 24(1), 100-111. Retrieved from https://files.eric.ed.gov/fulltext/EJ842123.pdf.

Alghazo, E. M., \& Naggar Gaad, E. E. (2004). General education teachers in the United Arab Emirates and their acceptance of the inclusion of students with disabilities. British Journal of Special Education, 31(2), 94-99.

Brackenreed, D. (2011). Inclusive education: Identifying teachers' strategies for coping with perceived stressors in inclusive classrooms. Canadian Journal of Educational Administration and Policy. Retrieved from https://files.eric.ed.gov/fulltext/EJ936704.pdf.

Campbell, J., Gilmore, L., \& Cuskelly, M. (2003). Changing student teachers' attitudes towards disability and inclusion. Journal of 
Intellectual and Developmental Disability, 28(4), 369-379. Retrieved from http://eprints.qut.edu.au/4305/1/4305.pdf.

Danne, C. J., \& Beirne-Smith M. (2000). Administrators' and teachers' perceptions of the collaborative efforts of inclusion in the elementary grades. Education, 121, 2.

Esteve, J. M. (2000). The transformation of the teachersee role at the end of the twentieth century: New challenges for the future. Educational Review, 52, 197- 207.

Forlin, C. (2001). Inclusion: Identifying potential stressors for regular class teachers. Educational Research,43(3), 235-245. Retrieved from https://www.tandfonline.com/doi/abs/10.1080/00131880110081017.

Forlin, C. (2010). Teacher education reform for enhancing teachers' preparedness for inclusion. International Journal of Inclusive education ,649 -653

Friedman, I. (2000). Burnout: shattered dreams of impeccable professional performance, Journal of Clinical Psychology, 56, 595-606.

Groenewald, T. (2004). A phenomenological research design illustrated. International Journal of Qualitative Methods, 3(1), 42-55.

Hopkins, M.L. (2014). The sources of work stress and coping resources for high school teachers in the Gauteng Province within different career stages. (Doctoral Dissertation). University of South Africa: Pretoria, South Africa.

Inciong, T. G., Capulong, Y. T., Quijano, Y. S., Gregorio, J. A., \& Gines, A. C. (2007). Introduction to Special Education: A Text Book for College Students. Rex Book Store, Inc.

Izci, E. (2005). Primary education candidates' competencies in "special education". Electronic Journal of Social Sciences, 4 (14), 106-114.

Jaoul, G., \& Kovess, V. (2004). Le burnout dans la profession enseignante [Teacher's burnout]. Annales Médico-Psychologiques, 162(1), 2635. https://doi.org/10.1016/j.amp.2003.03.002

Leatherman1, J. M., \& Niemeyer, J. A. (2005). Teachers' attitudes toward inclusion: Factors influencing classroom practice. Journal of Earl Childhood Teacher Education, 26(1), 23-36.

Leithwood, K. A., \& Riehl, C. (2003). What we know about successful school leadership. University of Nottingham: National College for School Leadership.

Lewis, R., Roache, J., \& Romi, S. (2011). Coping styles as mediator of teachers' classroom management techniques. Research in Education, 85(1), 53-68.doi: 10.7227/RIE.85.5

Nketsia, W., Saloviita, T., \& Gyimah, E. K. (2016). Teacher educators' views on inclusive education and teacher preparation in 
Ghana. International Journal of Whole Schooling, 12.

Orel, A., Töret. G., \& Zerey, Z. (2004). Examination of classroom teacher candidates' attitudes towards integration. Ankara University Faculty of Educational Sciences special education journal, 5 (1), 23-33.

Salend, S. J. (1998). Effective mainstreaming: Creating inclusive classrooms. New Jersey: Merill.

Sharma, U., \& Desai, I. (2002). Measuring concerns about integrated education in India. Asia and Pacific Journal on Disability, 5(1), 2-14.

Sharma, U., Forlin, C., \& Loreman, T. (2008). Impact of training on preservice teachers' attitudes and concerns about inclusive education and sentiments about persons with disabilities. Disability \& Society, 23(7), 773-785.

Skaalvik, E. M., \& Skaalvik, S. (2007). Dimensions of teacher self-efficacy and relations with strain factors, perceived collective teacher efficacy, and teacher burnout. Journal of educational psychology, 99(3), 611.

Sloan Nichols, A., \& LaPlanteSosnowsky, F. (2002). Burnout among special Education teachers in self-contained cross-categorical classrooms. Teacher Education and Special Education, 25(1), 71-86.

Snowman, J., \& Biehler, R. (2000). Psychology applied to teaching. New York, Boston. Houghton Mifflin Company.

Troman, G., \& Woods, P. (2001). Primary teachers' stress. New York: Rutledge/Falmer

Talmor, R., Reiter, S., \& Feigin, N. (2005). Factors relating to regular education teacher burnout in inclusive education. European Journal of Special Needs Education, 20(2), 215-229

Wood, T., \& McCarthy, C. (2002). Understanding and Preventing Teacher Burnout. ERIC Digest. 